\title{
Molecular Performance of Oil Palm (Elaeis Guineensis Jacq.) Origin Based on Microsatellite Marker for Low Lipase Trait
}

\author{
N U Angkat ${ }^{1 *}$, L A M Siregar $^{2}$, M Basyuni $^{3}$ \\ ${ }^{1}$ Graduate School of Agrotechnology, Universitas Sumatera Utara, Indonesia \\ ${ }^{2}$ Departement of Agriculture, Universitas Sumatera Utara, Indonesia \\ ${ }^{3}$ Department of Forestry, Universitas Sumatera Utara, Indonesia \\ *luthfi2004@yahoo.com
}

\begin{abstract}
Oil palms are one of the most increased expansion commercial crops in the tropics area other than the other plantation. As a leading of producers palm oil in the world, Indonesia produce 40.5 metric million tons of oil palm in 2018 and the most problem in CPO quality is free fatty acid content. The quality of palm oil is strongly influenced by the level of fruit maturity and free fatty acid content. Incomplete hydrolysis of lipases is in the release of monoacylglycerols (MAG) and diacylglycerols (DAG) in addition to free fatty acids (FFA). This study aimed to determine the genetic diversity and molecular performance of 15 Elaeis guineensis origin were analyzed using microsatellite marker. Results showed that mEgCIR_LIP03 was the informative marker based on polymorphic informative content (PIC) value is 1,00 and supported by electroporegram depicted 15 Elaeis guineensis origin were amplified with low lipase specific marker (190 bp-253 bp). The observed heterozigosity (Ho) 0,00 was lower than expected heterozigosity (He) 0,916 , indicating this population had high similarity. Relationship between genotype was exhibited by dendogram, it was divided in to 2 clusters in 0,54 similarity coefficient.
\end{abstract}

Keywords: allele, low lipase, microsatellite marker, molecular, oil palm

\section{Introduction}

Indonesia is the first palm oil producer in the world with 36,5 million metric tons of palm oil production in 2017 and increased to 40,5 million metric tons that is 5.5 million tons of it is for domestic consumption in the food industry [1] In fact, post harvesting and transportation processes is currently injure the fresh fruit bunch and affect the content in crude palm (CPO) quality within the increasing of free fatty acid (FFA) content [2]. The high oil content in the mesocarp makes it a rich substrate for lipase activity [3]. According to [4] post-harvest handling and processing of oil-rich palm fruit will increase contact between lipase and fat substrate, resulting in an increase in the hydrolysis of Triacilglycerol to free fatty acids. The higher FFA in $\mathrm{CPO}>5 \%$ is inappropriate for human consumption without properly purification [5].

However in the past, an effort for oil palm breeding improvement process could take from 8 to 10 years by determine the descendant of parents crosses, this time period has been 
reduce by using biotechnology tools [6]. The genetic diversity of E.guineensis has been reported using any difference marker depend on DNA target $[7,8]$. Microsatellite QTL mapping of lipase activity in oil palm has been studied [9] and the three lipases gene had high homology to demonstrated triacylglycerol lipases. The advantages of microsatellite marker are high information content, co-dominance and preferred for mapping, genetic analyses and marker assisted plant improvement program [10]. Successfully determining genotypes with low lipase activity allows the longer storage period for fruit bunch, increase the oil production and improve the quality of CPO. This study aimed to determine the genetic diversity and molecular performance of Elaeis guinensis to low lipase activity.

\section{Research Method}

\subsection{Plant material and DNA extraction}

Total 15 materials genetic of Elaeis guineensis were collected from Aek loba Estate Asahan, North Sumatera belong to PT. Socfin Indonesia are listed in Table 1. Total genomic DNA was extracted from leaves using modified cetyltrimethyl ammonium bromide (CTAB) procedure [11].

Table 1. Material genetic information

\begin{tabular}{cc}
\hline Accession & Family \\
\hline 3 & SL A1 \\
4 & SL A2 \\
9 & SL A3 \\
10 & SL A4 \\
15 & SL A5 \\
16 & SL A6 \\
21 & SL A7 \\
22 & SL A8 \\
27 & SL A9 \\
28 & SL A10 \\
33 & SL A11 \\
34 & SL A12 \\
39 & SL A13 \\
40 & SL A14 \\
45 & SL A15 \\
\hline
\end{tabular}

\subsection{PCR and Visualization of DNA Amplification}

The DNA region was amplified by PCR using microsatellite marker, mEgCIR_LIP03, see Table 2., it had a QTL mapping [9]. The DNA amplification were running at initial denaturation $95^{\circ} \mathrm{C}$ for $10 \mathrm{~min}$, followed by 35 cycles of denaturation at $94^{\circ} \mathrm{C}$ for $30 \mathrm{~s}$, annealing at $55^{\circ} \mathrm{C}$ for $1 \mathrm{~min} 15 \mathrm{~s}$, extension at $72^{\circ} \mathrm{C}$ and final elongation step at $72^{\circ} \mathrm{C}$ for $30 \mathrm{~min}$. The extracted DNA amplification banding profile was visualized by $2 \%$ agarose gel within $1 \mathrm{x}$ TBE buffer system. Electrophoresis is carried out with 70 volts electricity for $1 \mathrm{~h} 10 \mathrm{~min}$. The presence or absence of each DNA band was visualized by UV-transillumintor (UV Doc-its) and Gel Doc (U Doc its) and alleles were identified according to base pair size. 
Table 2. Microsatellite marker information

\begin{tabular}{cccc}
\hline $\begin{array}{c}\text { Microsatellite } \\
\text { marker }\end{array}$ & Forward Primer & Reverse Primer & $\begin{array}{c}\text { Time } \\
\text { Melting }\end{array}$ \\
\hline mEgCIR_LIP03 & TCAAAGAAACTTGTAGCATA & CATCCAGTAAGCTAACAC & $55^{\circ} \mathrm{C}$ \\
& TATCAAA & ACAAATG \\
\hline
\end{tabular}

\subsection{Data Analysis}

Each band that amplified by microsatellite marker was scored manually as a binary data with presence (1) and absence (0) band and to figure it out the alleles size was done by semiquantitative with standard curves using UVITEC Cambridge software [12]. The banding pattern is purpose to determine the presence of low lipase gene in each oil palm.

\section{Results and Discussion}

\subsection{DNA Amplification}

The result of amplification is to confirm the presence of low lipase gene within the plant tested using specific marker, mEgCIR_LIP03. All DNA samples were amplified and the banding pattern visible to one band as described in Figure 1. The length range amplified bands in this study were about $192 \mathrm{bp}-253 \mathrm{bp}$. Unfortunately, these narrow length of alleles generate difficulty to ensure that it was low lipase gene. According to previously study [13], this primer does not only validate the low lipase gene but also the high lipase activity. The high lipase activity was detected in two marker alleles (267bp-269bp) and the low lipase activity detected in one single marker allele $267 \mathrm{bp}$. However, this population has a potential gene to be candidates for low lipase genotype.

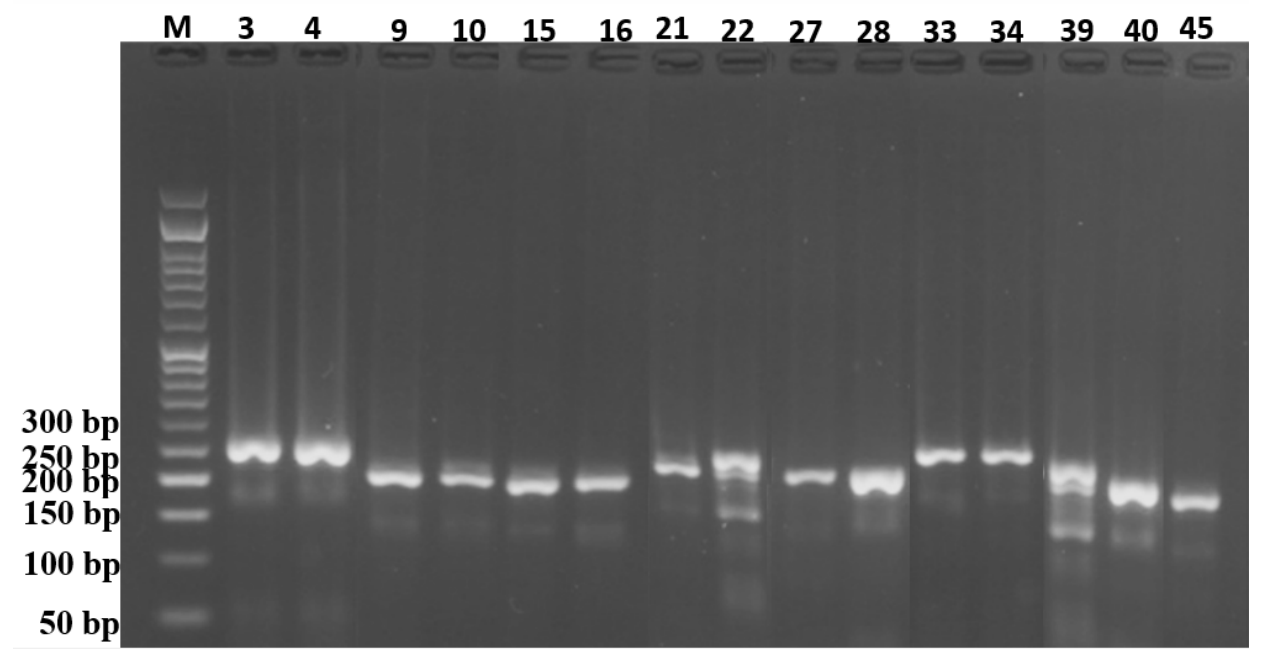

Fig 1. DNA Band Pattern result of amplification with mEgCIR_LIP03 specific primer $M=$ Ladeer; $3,4 . .45=$ DNA samples number according to accession number, $\mathrm{bp}=$ base pair 


\subsection{Genetic diversity structure}

Alleles frequencies was conducted according to [14] who defines two types of allel, high PIC value $>0,5$ and low PIC value $<0,05$ and this finding indicated the mEgCIRLIP_03 had a high PIC $(1,00)$ in the other word that is has potential primer to be used as molecular marker for low lipase breeding selection program, it was mentioned in [13] that mEgCIR_LIP03 was useful marker for introgression of low lipase trait in to other elite palm genotype. According to Table 3 observed heterozigosity $(0,00)$ was lower than expected heterozigosity $(0,916)$ indicated this population exhibited low diversity. In the previous study [15] dissimilarity of genotype reflected in higher Ho value.

Table 3. Microsatellice loci profile of oil palm. $\mathrm{N}=$ number of samples in population; $\mathrm{Na}=$ number of different alel; Number of effective alleles; $\mathrm{Ho}=$ observed heterozigosity; $\mathrm{He}=$ expected heterozigosity; $\mathrm{PIC}=$ polymorphic information content

\begin{tabular}{ccccccc}
\hline Locus & $\mathrm{N}$ & $\mathrm{Na}$ & $\mathrm{Ne}$ & $\mathrm{Ho}$ & $\mathrm{He}$ & $\mathrm{PIC}$ \\
\hline mEgCIR_LIP03 & 45 & 13,000 & 11,842 & 0,000 & 0,916 & 1,00 \\
\hline
\end{tabular}

The genetic analyses of 15 origin of oil palm using Gower General Similarity Coefficient [16] detected 2 main clusters in 0,54 similarity coefficient, see Figure 2., which were "A" cluster and "B" cluster. The B cluster was branched in to two sub cluster "A" cluster has $45,15,40,16,10,9$ origin accession number as its group member, and "B" cluster has $28,39,27,21,3,34,22,33,4$ as its group member. Cluster was formed according to base pair size so that indicate the members in the same group has a closer base pair size (allele length). The cluster was not formed by the family, although there were family difference among the population. Selection program in each generation cause the decrease of genetic bases of oil palm population that leaving the gen sources that has closer relationship [17]. However there is a little variability in this population.

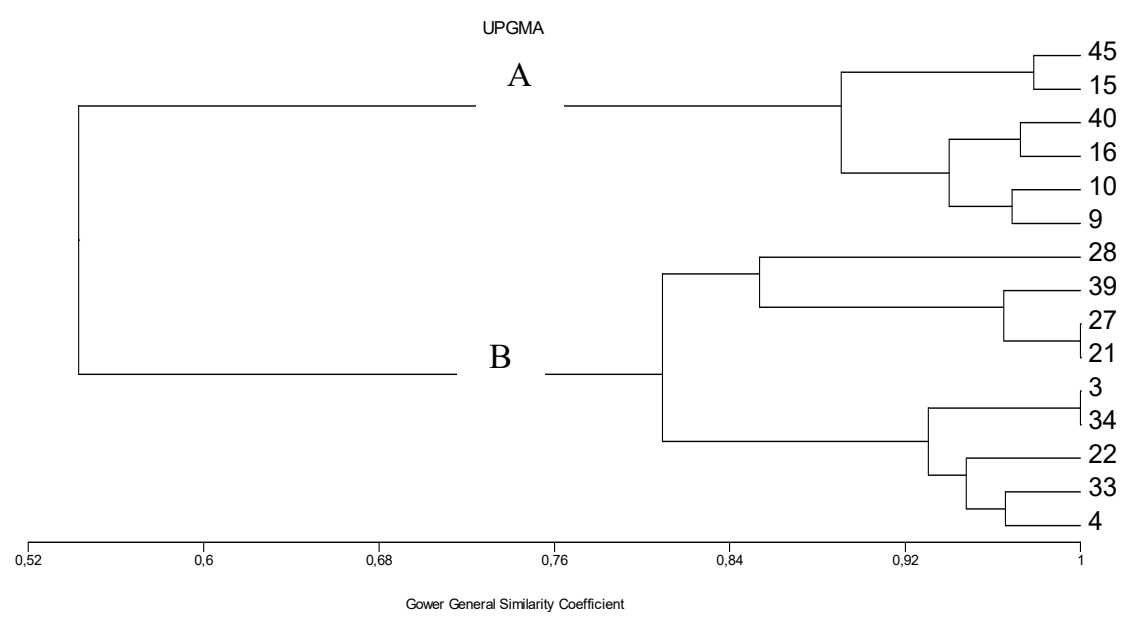

Fig 2. Dendogram of 15 Elaeis guineensis origin by UPGMA program based on base pair size using the Gower General Similarity Coefficient 1971 


\section{Conclusion}

The mEgCIR_LIP03 are informative marker to detected lipase gene activity in oil palm and the availability of the other specific marker of low lipase activity was suggested. The 15 oil palm were evaluated a potential genotype to be a low lipase genotype. There is a little variability within the population even the oil palm through any crossing selection.

\section{Acknowledgment}

The authors are grateful to PT. Socfin Indonesia for support on this study and the Universitas Sumatera Utara

\section{References}

[1] USDA Foreign Africulture Service :Indonesia Oilseed Products and Annual. Gain Report Number: 1807 (2018)

[2] Indonesia Oil Palm Research Institute (IOPRI): Oil Palm Cultivation. Indonesian Oil Palm Research Institute. Medan (2006)

[3] Sambanthamurthi, R., O O, K.C and Parman, S.H: Factors affecting lipase activity in Elaeis guineensis mesocarp. Plant Physiology \& Biochemistry 33, 353-359 (1995)

[4] Wong, Y.T., Kushairi, A., Rajanaidu, N., Osman, M., Wicknesmwari, R., Sambhanthamurti, R: Screening of wild oil palm (Elaeis guineensis) germplasm for lipase activity. Journal of Agricultural Science. doi:10.1017/S0021859615001112 (2015)

[5] Codex , A./FAO/WHO : Norme alimentaire pour huiles et graisses. CODEX-STAN 210. 9 (2005)

[6] Arias, D., C, Montoya., H. Romero. : Moleculer characterization of oil palm Elaeis guineensis Jacq. Materials from Cameroon. Plant Genetic Resources. Characterization and Utilization 1-9 (2013).

[7] Bilotte, N., Risterucci, A.M., Barcelos, E., Noyer, J.L., Amblard, P., Baurens, F.C. Developmental, characterisazion and across-taxa utility of oil palm (Eleais guineensis Jacq.) microsatelite marker. Genome. 44: 413-425 (2001)

[8] Putri, L A P., M.Basyuni., E.S. Bayu., D, Arvita., D, Arifyanto., I, Syahputra.: Identification of moleculer performance from oil palm clones based on SSR marker. IOP Conf Series. Earth and Environmental Science 126012149 (2018).

[9] Domonhédo, H., Cuéllar, T., Espeout, S., Droc, G., Summo, M., Rivallan, R., Cros, D., Nouy, B., Omore, A., Nodichao, L., Arondel, F., Ahanhanzo, C., Bilotte, N. Genomic structure, QTLmapping, and molecular markers of lipase genes responsible for palm oil acidity in the oil palm (Elaeis guineensis Jacq.). Tree Genetics \& Genomes (2018) 14:69. https// doi.org/10.1007/s11295-018-1284-7 (2018).

[10] MC Couch SR, Teytelman L, Xu Y, Lobos KB, Clare K, Walton M, Fu B, Maghirang R, Li Z, Xing Y, Zhang Q, Kono I, Yano M, Fjellstrom R, Declerck G, Schneider D, Cartinhour S, Ware D, Stein L. Development and mapping of 2240 new SSR markers for rice (Oryza sativa L.) DNA Research 9: 257-279 (2002) 
[11] Orozco-Castillo, K..J. Chalmers, R. Waugh,W.Powell : Detection of genetic diversity and selective gene introgression in coffee using RAPD markers. Theer.Appl.Gent 87 : 934-940 (1994).

[12] Basyuni M, Prayogi H, Putri LAP, Syahputra I, Siregar ES, Risnasari I, Wati R, Arifiyanto D. RAPD markers on genetic diversity in three populations of pisifera type of oil palm (Elaeis guineensis) IOP Conf. Ser.: Earth Environ. Sci. 130012050 (2018)

[13] Morcillo, F. Cros, D., Bilotte, N., Ngando-Ebongue, G-F., Domonhédo, H., Pizot, M., Cuéllar, T., Espéout, S., Dhouib, R., Bourgis, F., Claverol, S., Tranbarger, T.J., Nouy, B., Arondel, V. Improving palm oil quality through identification and mapping of the lipase gene causing oil deterioration.. Nature Communications 4, Article number: 2160 doi:10.1038/ncomms3160 (2013)

[14] Marshall, D.R. and Brown, A.H.: Optimum sampling strategis in genetic conservation. In Franked $\mathrm{OH}$ and Hawkes $J G$ (eds) Genetic Resources for Today and Tomorrow. Cambridge, London: Cambridge University Press, pp.53-80 (1975).

[15] Maizura L., C K Teh., W. Ratnam .: Genetic diversity of Elaeis oleifera (HBK) Cortes pupulation using cross species SSRs: implication's for germplasm utilization and conservation (2017)

[16] Gower, J.C.: A Genereal Coefficient of Similarity and Some of Its properties. Biometrics. (1971)

[17] Sayekti, U., U Widyastuti., N. T. Mathius. : Genetic diversity of the Angola-originated Oil Palm (Elaeis guineensis Jacq) Using SSR marker. J Agron Indonesia 43 (2): 140-146 (2015). 